\title{
ASSESMEN PORTOFOLIO DALAM PEMBELAJARAN KONTEKSTUAL TERHADAP KEMAMPUAN DASAR KOGNITIF DAN KEMAMPUAN BAHASA ANAK
}

\author{
Ni Nyoman Lisna Handayani a \\ aSTAHN Mpu Kuturan Singaraja \\ alisnahandayani201@gmail.com
}

(Diterima: 13 Januari 2022; Direvisi: 17 Januari 2022; Diterbitkan: 31 Januari 2022)

\begin{tabular}{l}
\hline Keywords: \\
\hline portfolio-based \\
approach to \\
contextual \\
learning, basic \\
cognitive abilities \\
and language skills
\end{tabular}

Kata kunci: assesmen portofolio dalam pembelajaran kontekstual, kemampuan dasar kognitif, dan kemampuan bahasa.

\begin{tabular}{l} 
Abstract \\
\hline This study uses an experimental research pattern The \\
Posttest-Only Control-Group Design. The research \\
population is all children of group B TK Lab Undiksha. The \\
sample in this study amounted to 41 people. Data on \\
children's basic cognitive abilities and language skills were \\
collected by observation using an observation sheet. The data \\
analysis used was MANOVA (Multivariat Analysis of \\
Variance) assisted by SPSS 17.00 for windows. The results \\
showed that: First, portfolio assessment in contextual \\
learning had an effect on students' cognitive abilities (F= \\
28.56 p<5\%). Second, portfolio assessment in contextual \\
learning has an effect on students' language skills (F=38.75 \\
p<5\%). Third, portfolio assessment in contextual learning \\
has a significant effect on students' basic cognitive abilities \\
and language skills (F=17.59 $p<5 \%$ ).
\end{tabular}

\begin{tabular}{l} 
Abstrak \\
\hline Penelitian ini mengguna penelitian eksperimen pola \\
The Posttest-Only Control-Group Desain. Populasi \\
penelitian adalah seluruh anak kelompok B TK Lab \\
Undiksha. Sampel pada penelitian ini berjumlah 41 \\
orang. Data kemampuan dasar kognitif dan \\
kemampuan bahasa anak dikumpulkan dengan \\
obsrevasi menggunakan lembar observasi. Analisis \\
data yang digunakan adalah MANOVA (multivariat \\
Analysis of Variance) berbantuan SPSS 17.00 for \\
windows. Hasil Penelitian menunjukkan bahwa: \\
Pertama, assesmen potofolio dalam pembelajaran \\
kontekstual berpengaruh terhadap kemampuan \\
kognitif siswa (F= 28,56 p<5\%). Kedua, assesmen \\
potofolio dalam pembelajaran kontekstual \\
berpengaruh terhadap kemampuan bahasa siswa (F=
\end{tabular}


38,75 p<5\%). Ketiga, assesmen potofolio dalam pembelajaran kontekstual berpengaruh secara signifikan terhadap kemampuan dasar kognitif dan kemampuan bahasa siswa $(\mathrm{F}=17,59 \mathrm{p}<5 \%)$.

\section{PENDAHULUAN}

Pendidikan merupakan unsur sentral yang berpengaruh terhadap peningkatan sumber daya manusia. Tingkat pendidikan menjadi ukuran tingkat kemampuan berfikir seseorang. Mutu pendidikan yang dimaksudkan merupakan pendidikan yang kontekstual dan utuh untuk mengarahkan anak pada pendidikan antisipatif guna menghadapi tantangan era globalisasi. Dalam konteks itu, ilmu memiliki tiga dimensi yaitu dimensi ontology, epistimologi dan aksiologi. Ontologi keilmuan berbicara mengenai obyek ilmu tersebut, yang dalam perkembangannya didasarkan pada prosedur ilmiah yang menganut verifikasi terbuka, obyektif dan jujur dalam satu bingkai epistimologi keilmuan, yang diharapkan dapat memberikan kesejahteraan pada kehidupan manusia sebagai dimensi aksiologi.

Pembelajaran yang bermakna tidak saja berorientasi pada kemampuan kognitif melainkan juga berorientasi pada pengalaman, lingkungan dan hal- hal yang sifatnya kontruktivis. Melalui pembelajaran yang bermakna, siswa akan mampu mengaitkan pengalaman pribadinya dengan pengetahuan baru yang mereka dapatkan dari lingkungan sekitar, teman- teman dan sumber belajar lainnya yang bermakna. Serta mengingat adanya reformasi pada tubuh pengetahuan dan teknologi komunikasi, anak selayaknya dilatih bagaimana seharusnya menghadapi berbagai persoalan yang akan dihadapi anak baik di lingkungan rumahnya, sekolahnya maupun masyarakat di era globalisasi ini.

$$
\text { Peningkatan kualitas }
$$

pendidikan di Indonesia akan dapat terlaksana dengan baik jika didukung oleh komponen-komponen pendidikan yang berkualitas. Berbagai isu strategis pendidikan di Indonesia terus bergulir dan belum terpecahkan, meskipun berbagai upaya sudah dilaksanakan secara terus-menerus oleh berbagai pihak. Isu terbesar dari berbagai isu strategis tersebut adalah kualitas, relevansi, pemerataan, dan manajemen pendidikan (Nanang Hanafiah,2009).

Salah satu komponen penting yang memegang peran strategis dalam peningkatan kualitas pendidikan di Indonesia adalah guru. Untuk menciptakan hubungan yang baik antara pendidik dan anak, maka perlu dijembatani oleh intensitas keterlibatan emosi dalam belajar, tidak dipungkiri ketika kita ditanya mata pelajaran yang paling menarik dan disukai semasa kita sekolah tentu yang kita ingat adalah mata pelajaran dari pendidik yang kita sukai, perasaan ini 
menciptakan dalam diri kita suatu ikatan emosional terhadap belajar yang mematri pada pelajaran tersebut pada ingatan kita.

Berdasarkan hasil observasi yang dilaksanakan di TK Negeri Lab Undiksha khususnya kelompok B Berdasarkan hasil observasi awal yang telah dilakukan penulis untuk mengetahui kemampuan kognitif khususnya pada aspek menulis anak, diketahu bahwa anak banyak mengalami kebingungan di dalam menentukan menulis kalimat sesuai intruksi guru.

Pendidik adalah faktor penting dalam lingkungan belajar dan kehidupan anak, peran pendidik bukan hanya sebatas pemberi ilmu pengetahuan akan tetapi pendidik adalah rekan belajar, model, pembimbing, fasilitator, dan motivator penentu kesuksesan anak dalam belajar. Jika hal ini benar-benar diresapi dan dipraktekkan setiap pendidik khususnya pendidik bangsa ini, penulis meyakini pendidik adalah sosok yang akan selalu diidolakan oleh anak, mereka akan merasa nyaman dan betah berlama-lama di dalam kelas, waktu pertemuan serasa tidak akan pernah usai karena pendidik tahu apa yang dibutuhkan oleh anaknya.

Berdasarkan preposisi di atas, tampak bahwa pembelajaran di TK B Lab Undiksha nampaknya belum mencerminkan kreativitas dan pembelajaran yang bermakna. Budaya belajara yang riang gembira belum terlihat optimal. Situasi proses belajar seperti ini tidak akan mampu meningkatkan kemampuan kognitif dan kemampuan bahasa anak.

Asesmen portofolio yang diterapkan di PAUD hendaknya memfasilitasi anak usia dini untuk menilai hasil kerjanya sendiri. Asesmen portofolio sangat baik digunakan untuk mengetahui perkembangan kognitif anak secara berkesinambungan Portofolio merupakan kumpulan karya anak yang berupa unjuk kerja dari refleksi perkembangan kognitif dan motoric yang dimiliki oleh anak. Selain itu, kumpulan karya yang berkesinambungan akan memperkuat kaitan antara pembelajaran dan penilaian.

Kemampuan berbicara anak usia dini sejak awal sebaiknya sudah dilatihkan agar anak terbiasa untuk berbicara tanpa ada perasaan malu. Pentingnya pembiasaan ini akan berpengaruh pula terhadap kemampuan kognitif anak usia dini. Banyak metode ataupun strategi belajar yang bisa dilakukan seperti bercerita, bernyanyi ataupun bermain. Kegiatan pembelajaran kontekstual dengan asesmen portofolio ini, menekankan bahwa hasil karya anak dikumpulkan secara terus menerus sehingga dapat diketahui peningkatan yang dialami anak berdasarkan hasil karya tersebut. Selain itu penilaian ini juga memperhatikan komponen asesmen diri anak dan kriteria penilaian yang digunakan untuk meningkatkan kemampuan menulis anak. 
Disamping itu pula pembagian tugas yang diberikan guru untuk dikerjakan oleh anak harus berkaitan dengan kehidupan nyata peserta didik serta berada pada wilayah perkembangannya, sehingga anak mampu mengerjakan tugas-tugas yang diberikan oleh guru dengan baik. Tugas-tugas yang diberikan tersebut kemudian dianalisis untuk mengetahui perkembangan anak. Bertitik tolak dari uraian tersebut di atas maka asesmen portofolio merupakan salah satu alternatif yang tepat untuk dilakukan oleh guru di dalam mengelola pembelajaran yang menggunakan assesmen portofolio dalam pembelajaran kontekstual.

Disamping itu pula asesmen portofolio dalam proses pembelajaran memerlukan kreatifitas, inovasi yang memang sifatnya kontekstual. Pengumpulan karya- karya yang dikerjakan oleh anak bisa dari mediamedia atau sumber belajar sederhana yang ramah lingkungan yang bisa mereka peroleh dengan mudah dari lingkungan sekitarnya. Pengumpulan karya- karya yang telah dihasilkan oleh anak sebaiknya dapat disimpan dengan baik agar dapat mendukung perkembangan asesmen secara berkelanjutan.

\section{Berdasarkan} rasional permsalahn diatas diperlukan suatu upaya agar mampu membenahi pola pembelajaran yang telah dilakukakan agar mampu meningkatkan kemampuan kognitif dan kemampuan berbicara anak. Peneliti berupanya meminimalisir permasalahan tersebut melalui penelitian yang berjudul "Implementasi Pembelajran Kontekstual Berbasis Portopolio Dalam Upaya Meningkatkan Kemampuan Dasar Kognitif Anak kelompok B TK Negeri Lab Undiksha". Secara khusus tujuan penelitian ini yaitu: (1) Untuk mengetahui perbedaan assesmen portofolio dalam pembelajaran kontekstual terhadap kemampuan dasar kognitif anak kelompok B TK Lab Undiksha (2) Untuk mengetahui perbedaan assesmen portofolio dalam pembelajaran kontekstual terhadap kemampuan Bahasa anak kelompok B TK Lab Undiksha. (3) Untuk mengetahui secara simultan perbedaan assesmen portofolio dalam pembelajaran kontekstual terhadap kemampuan dasar kognitif dan kemampuan Bahasa anak kelompok B TK Lab Undiksha.

\section{METODE}

Penelitian ini dilakukan di TK Lab Undiksha dengan tujuan mengetahui kemampuan dasar kognitif dan kemampuan bahasa anak kelompok B TK Lab Undiksha setelah kegiatan pembelajarannya diterapkan melalui assesmen portofolio. Rancangan penelitian yang dilakukan menggunakan rancangan eksperimen semu (quasi eksperimen). Populasi adalah wilayah dan kumpulan anak yang memiliki karakteristik tertentu dan ingin diteliti. Populasi dalam penelitian ini adalah semua anak TK Lab Undiksha. Sampel dalam penelitian ini dikelompokkan menjadi 
dua yaitu kelompok eksperimen dan kelompok kontrol yang dilakukan melalui teknik random dalam pengambilan sampelnya.

Pengundian yang dilakukan akhirnya menetapkan kelompok B2 ditetapkan sebagai kelas eksperimen dan kelompok B1 ditetapkan sebagai kelas kontrol. Sebelum uji hipotesis dilakukan untuk mengetahui kemampuan kognitf dan kemampuan Bahasa anak yang dibelajarkan dengan assesmen portofolio pada kelas eksperimen dan pembelajaran konvensional pada kelompok control maka akan dilaukan uji prasyarat analisis data. Uji yang dilakukan meliputi uji normalitas sebran data, uji homogenitas varians, dan uji korelasi antar variabel terikat.

Data yang diperoleh dalampenelitian ini selanjutnya akan dianalisis melalui dua jenis analisis yaitu

analisis deskriftif dan analisis multivariat MANOVA (Multivariate Analisis of Variance). Untuk mendeskripsikan kemampuan dasar kognitif, dan kemampuan bahasa antara anak yang dibelajarakan dengan asesmen portofolio berbasis pembelajaran kontekstual dengan anak yang belajar dengan model konvensional digunakan analisis deskriptif. Sedangkan untuk menguji dugaaan pengaruh assesmen portofolio terhadap kemampuan dasar kognitif dan kemampuan Bahasa digunakan analisis MANOVA.

\section{HASIL DAN PEMBAHASAN}

Variabel terikat penelitian ini adalah kemampuan kognitif dan kemapuan bahasa sebagai hasil perlakuan antara pengaruh assesmen portofolio dalam pembelajaran kontekstual dan model pembelajaran konvensional. Analisis deskriftif yang dilakukan mampu mendeskripsikan beberapa hal yaitu: 1) kemampuan kognitif anak yang belajar menggunakan assesmen portofolio dalam pembelajaran kontekstual, 2) kemampuan bahasa anak yang dibelajarkan dengan model assesmen portofolio dalam pembelajaran kontekstual, 3) kemampuan kognitif yang belajar menggunakan model konvensional, 4) kemampuan bahasa yang dibelajarkan dengan model konvensional.

Keempat distribusi tersebut dijabarkan rata-ratanya sebagai deskripsi awal masing- masing sebaran data. Rekapitulasi analisis dekriptif dapat disajikan pada tabel 1 berikut ini.

Tabel 1. Rekapitulasi Hasil Perhitungan Skor Kemampuan Kognitif dan Kemampuan Bahasa Anak 


\begin{tabular}{ccccc} 
Statistik & $\mathbf{A}_{\mathbf{1}} \mathbf{Y}_{\mathbf{1}}$ & $\mathbf{A}_{\mathbf{1}} \mathbf{Y}_{\mathbf{2}}$ & $\mathbf{A}_{\mathbf{2}} \mathbf{Y}_{\mathbf{1}}$ & $\mathbf{A}_{\mathbf{2}} \mathbf{Y}_{\mathbf{2}}$ \\
\hline Rerata & 112 & 69,6 & 104,7 & 59,6 \\
\hline Median & 114 & 72 & 106 & 60 \\
\hline Modus & 111 & 74 & 106 & 63 \\
\hline $\begin{array}{c}\text { Std. } \\
\text { Deviasi }\end{array}$ & 7,23 & 10,5 & 9,89 & 12,28 \\
\hline Varians & 61,6 & 109,2 & 95,3 & 148,5 \\
\hline Rentangan & 29 & 40 & 43 & 55 \\
\hline Minimum & 96 & 48 & 78 & 35 \\
\hline Maksimum & 125 & 88 & 121 & 90
\end{tabular}

Keterangan:

$\mathrm{A}_{1} \mathrm{Y}_{1} \quad$ : skor kemampuan kognitif yang dibelajarkan dengan assesmen portofolio dalam pembelajaran kontekstual

$\mathrm{A}_{1} \mathrm{Y}_{2}$ : skor kemampuan bahasa yang dibelajarkan dengan assesmen portofolio dalam pembelajaran kontekstual

$\mathrm{A}_{2} \mathrm{Y}_{1}$ : skor kemampuan kognitif yang dibelajarkan dengan model konvensional. $\mathrm{A}_{2} \mathrm{Y}_{2}$ : skor kemampuan bahasa yang dibelajarkan dengan model konvensional.

Mengingat penelitian ini yang diteliti adalah kemampuan kognitif dan keamapuan bahasa dengan menerapkan model pembelajaran assesmen portofolio dalam pembelajaran kontekstual yang mana model ini memiliki kecenderungan untuk menanamkan ranah afektif, kognitif dan psikomotor. Kemampuan kognitif akan berhubungan dengan dimensi pengetahuan yang dimiliki oleh anak usia dini, kemampuan Bahasa erat hubungannya dengan aspek apektif dan psikomotor anak.

Assesmen portofolio dalam pembelajaran kontekstual di PAUD akan sangat bermanfaat karena sifatnya dekat dengan keseharian anak. hal- hal yang bersifat kontekstual ini akan mengembangkan kemampuan Bahasa dan meningkatkan kemampuan kognitif anak menjadi lebih baik.

Pendidikan taman kanakkanak merupakan hal yang sangat penting mendapatkan perhatian agar dalam pelaksanaannya mampu memberikan hal terbaik untuk anak didik. Spirit pembelajaran berpusat pada anak (student centered learning) telah diterjemahkan oleh guru untuk merencanakan pembelajaran selanjutnya dengan menginovasikan pembelajaran agar bermakna bagi anak usia dini. Salah satunya bentuknya yang kontekstual adalah pengenalan konsep warna melalui bermain kelompok.

Melalui pembelajaran yang sifatnya kooperatif anak akan terbiasa bergaul dengan temannya, terlatih kemampuan sosialnya dalam 
berinteraksi, terlatih kemampuan berbicaranya. Hal ini tentu memberikan kontribusi positif terhadap aspek perkembangan kognitif dan perkembangan Bahasa anak.

Dalam medote bermain kelompok, diharapkan akan terjalin komunikasi antar anak untuk berbagi pendapat dan interaksi sosial sehingga diharapkan dapat meningkatkan kemampuan berbahasa anak. Berdasarkan hal tersebut anak akan merasa senang dalam belajar, tidak malu- malu Ketika menyampaikan pendapat. Hal ini tentu akan melatih rasa percaya diri anak.

Sementara itu, assesmen portofolio dalam pembelajaran kontekstual melalui metode bermain kelompok dapat memberikan pembelajaran dalam PBM menjadi lebih aktif dan akan menumbuhkan kemampuan kognitif anak. Metode ini memberikan dampak yang baik terhadap peningkatan kemampuan kognitif dan kemampuan Bahasa anak. Anak usia dini melalui pengenalan hal- hal yang kontekstual akan menjadi lebih paham dengan materi yang mereka pelajari.

Kemampuan Bahasa anak biasanya tercermin dalam emosi positif, seperti rasa gembira, nyaman, terbuka, kasih sayang, dan paling penting untuk mempermudah siswa belajar dari apa yang dipelajarinya. Dengan adanya emosi positif ini anak dapat dibekali nilai-nilai sosial dan keterampilan sosial dalam upaya pembentukan kepribadian yang baik serta terlatih untuk memiliki rasa percaya diri dalam mengerjakan tugas yang diberikan serta tidak malu untuk berpendapat.

Guna menumbuhkan kemampuan bahasa yang baik dan positif dalam kegiatan belajar kontekstual maka, dalam penelitian ini lebih awal anak diajak untuk menciptakan lingkungan belajar yang indah dan nyaman, seperti bersamasama menghias kelas, membuat katakata motivasi, membuat jadwal piket, membuat hiasan dari barang sisa sehingga menjadi hiasan gantungan yang menawan. Mengkondisikan situasi pembelajaran yang menyenangkan, seperti: menggunakan instrumental (musik tanpa lirik), bernyanyi, membuat kesepakatan, membuat yel-yel, dan instruksi siap siaga.

Asesmen portofolio mampu membantu anak dalam menyelesaikan masalah yang diberikan dalam bentuk tugas kinerja karena tugas-tugas tersebut masih berada dalam wilayah pengetahuan anak atau masih berkaitan dengan pengetahuan yang sudah dimiliki oleh anak.Disamping itu pula di dalam menyelesaikan tugas-tugas yang diberikan, anak juga memerlukan penalaran dan kemampuan perhitungan matematis. Kemampuan penalaran yang diperlukan oleh anak dalam menyelesaikan tugas-tugas tersebut sangat tergantung kepada kemampuan verbal yang dimilikinya.

Berdasarkan uraian tersebut terlihat adanya kesesuaian antara 
hakikat kemampuan bahasa dengan Asesmen portofolio. Hal ini sejalan dengan hakikat Asesmen portofolio berbasis Asesmen portofolio yang dalam proses pembelajarannya kepada hal- hal yang sifatnya kontekstual. Halhal yang sifatnya dekat dengan lingkungan anak seperti bercerita tentang lingkungan rumah akan memudahkan anak untuk bercerita atau berbahasa dengan baik.

Berbeda dengan pembelajaran konvensional yang mana anak hanya mendengarkan cerita guru akaan memberikan hasil yang berbeda dengan pembelajaran yang mnegaktifkan anak untuk berani berbicara. Perbedaan proses pembelajaran kontekstual berbasis portopolio dengan pembelajaran konvensional menunjukkan perbedaan yang amat menjolok hasilnya. Dengan adanya perbedaan pada proses pembelajaran, maka sangat memungkinkan jika kemampuan bahasa anak yang mengikuti pembelajaran dengan pembelajaran kontekstual berbasis portopolio lebih baik daripada kemampuan bahasa anak yang mengikuti pembelajaran konvensional.

$$
\text { Pengaruh simultan }
$$

pembelajaran kontekstual berbasis portopolio terhadap kemampuan dasar kognitif dan kemampuan bahasa menunjukkan keunggulan yang dirasakan setelah dimplementasikannya assesmen portofolio dalam pembelajaran seperti terdokumentasikannya karya anak secara berkeinambungan yang bisa digunakan untuk melihat perkembangan belajar anak secara berkelanjutan dalam kurun waktu. Perkembangan ini bisa meningkatkan motivasi dan semangat belajar anak untuk menghasilkan pembelajaran yang lebih baik.

Proses pembelajaran yang efektif perlu diimplementasikan melalui inovasi atau ide kreatif guru untukmenumbuhkan kemampuan dasar kognitif dan kemampuan bahasa guru perlu menginovasikan mediamedia pembelajaran yang siftnya kontekstual, menantang dan menyenangkan. Melalui hal ini anak akan lebih antusias untuk belajar, merasa nyaman untuk belajar, dan berani untuk menyampaikan keinginannya dalam pembelajaran tanpa rasa malu.

Peran pendidik dalam membangkitkan kemampuan kognitif dengan menciptakan kesenangan dalam belajar, menjalin hubungan dan menyingkirkan segala ancaman dari suasana belajar sehingga emosi yang terjalin adalah emosi positif. Dengan demikian, kemampuan dasar kognitif anak dan kemampuan bahasa anak yang mengikuti pembelajaran dengan pembelajaran kontekstual berbasis portofolio lebih baik dibandingkan dengan kemampuan dasar kognitif anak dan kemampuan bahasa anak yang mengikuti pembelajaran konvensional. Pembelajaran memiliki empat komponen utama, yaitu tujuan, materi, metode/media, dan penilaian. Keempat komponen tersebut tidak 
dapat dipisahkan dan saling melengkapi satu dengan yang lainnya sehingga perlu mendapat perhatian demi menciptakan pembelajaran yang kondusif.Komponen penilaian merupakan salah satu komponen yang perlu mendapat perhatian.

Mengacu pada temuan diatas maka, guru anak usia dini hendaknya lebih awal bisa mengkemas pembelajaran seefektif mungkin dan bermakna agar anak merasa bersemangat untuk belajar. Semangat yang tinggi dimiliki anak dalam belajar akan memberikan hasil yang bagus dalam kegiatan pembelajaran. Assesmen portofolio dalam pembelajaran kontekstual memberikan kesempatan kepada anak dalam menggali dan mengembangkan keteampilan yang dimiliki oleh masing- masing anak. Anak dalam kegiatan belajar ini akaan merasa nyaman untuk belajar, berani menyampaikan gagasan, berani berbicara.

Assesmen portofolio akan meningkatkan kemampuan kognitif anak melalui pengumpulan karya yang terdokumentasi dengan baik. Kegiatan belajar mengajar di PAUD ini relevan dengan dengan dunia anak usia dini terutama yang sifatnya kontekstual. Kegiatan pembelajaran seperti ini akan berdampak terhadap kemampuan kognitif dan kemampuan bahasa anak.

\section{KESIMPULAN}

Penelitian di TK Lab Undiksha berhasil menunjukkan tiga temuan yang dapat dijadikan kesimpulan dalam penelitian ini yaitu: Pertama, terdapat peningkatan kemampuan dasar kognitif anak sebesar 28,56 setelah anak mengikuti pembelajaran dengan assesmen portofolio dalam pembelajaran kontekstual pada anak kelompok B TK Lab Undiksha. Kedua, terdapat peningkatan kemampuan bahasa anak sebesar 38.75 setelah anak mengikuti pembelajaran dengan assesmen portofolio pada anak kelompok B TK Lab Undiksha. Ketiga, secara simultan terdapat peningkatan kemampuan dasar kognitif dan kemampuan bahasa sebesar 17,59 setelah anak mengikuti pembelajaran dengan assesmen portofolio dalam pembelajaran kontekstual pada anak kelompok B TK Lab Undiksha.

Mengacu pada temuan penelitian ini maka, agar kempuan dasar kognitif dan kemampuan Bahasa anak usia dini dapat tercapai secara maksimal maka guru hendaknya mengembangkan kemampuan kognitif dan bahasa melalui berbagai bentuk latihan yang lebih intensif. Penelitian lanjutan yang berkaitan dengan asesmen portofolio di PAUD perlu dilakukan pada sekolah lain dengan menggunakan variabel yang berbeda sehingga mampu memberikan hasil- hasil penelitian yang lebih valid.

\section{DAFTAR PUSTAKA}

Agung, A. A. G. (2017). Metodologi Penelitian Kuantitatif (Perspektif 
Manajemen Pendidikan). Singaraja: Universitas Pendidikan Ganesha.

Andi, Yudha. (2009). Kenapa Guru Harus Kreatif. Bandung: Dar Mizan.

Arikunto, S. (2019). Prosedur Penelitian. Jakarta: Rineka cipta.

Budiningsih, Asri. (2005). Belajar dan Pembelajaran. Jakarta: Rineka Cipta.

Buzan, Tony. (2002). Sepuluh Cara jadi Orang yang Jenius Kreatif. Jakarta: Gramedia Pustaka Utama.

Dahar, R. W. (2011). Teori-teori Belajar. Bandung: Erlangga.

Dantes, Nyoman. (2012). Metode Penelitian. Yogyakarta : CV Andi Offset.

Dantes, Nyoman. (2012). Statistik Test. Singaraja : Undiksha.

Dimyati dan Mudjiono. (2015). Belajar dan Pembelajaran. Jakarta: Rineka Cipta.

Hanafiah dan Suhana. (2012). Konsep Strategi Pembelajaran. Bandung: PT Refrika Aditama.

Mudjia Rahardjo. (2017). Studi Kasus dalam Penelitian Kualitatif Konsep dan Prosedurnya. Jurnal Ilmiah. Malang: Universitas Islam Negeri Maulana Malik Ibrahim Malang.

Rusyan, A. Tabrani. (2005). Proses Belajar Mengajar yang Efektif Tingkat Pendidikan dasar. Bandung: Bina Budaya.
Sadiman, dkk. (2006). Media Pendidikan. Jakarta: PT RajaGrafindo Persada.

Schement, J. R. (2002). Encyclopedia of Cpmmunication and Information (Volume 1). New York: McMilland Reference.

Slameto. (2003). Belajar dan Faktor-faktor yang Mempengaruhinya. Jakarta: Trineka Cipta.

Suami, Dewa Ayu. (2016) Penerapan assesmen portofolio dalam pembelajaran kontekstual Untuk Meningkatkan Minat dan Hasil belajar IPS Anak Kelas IV SDN 21 Dauh Puri Denpasar. Tesis. Program Pascasarjana Undiksha Singaraja.

Sudjana, Nana. (2005). Srategi Pembelajaran. Bandung: Falah Produktion.

Sugiyono. (2008). Metode Penelitian Pendidikan Pendekatan Kuantitatif, Kualitatif, dan R E D. Bandung: Alfabeta.

Sugiyono. (2017). Metode Penelitian Kuantitatif, Kualitatif, dan RED. Bandung: Alfabeta, CV.

Sukmadinata, Syaodih Nana. (2004). Landasan Psikologi Proses Pendidikan. Bandung: Remaja Rosdakarya.

Sukreni, Wayan. (2017). Penerapan Pembelajaran Inkuiri Untuk Meningkatkan Minat Dan Hasil Belajar Anak Kelompok B Tk Kumara Jati Denpasar. e-Journal Program Pascasarjana Universitas Pendidikan Ganesha Program Studi 
Pendidikan Dasar (Volume 4

Tahun 2017).

White, P. E. (1992). Women and minorities in science and engineering: An update. Washington, DC: National Science Foundation.

Winarno. (2011). Dinamika Peradaban Global \& Pengaruhnya Bagi Negara Bangsa. Solo: FKIP UNS. 